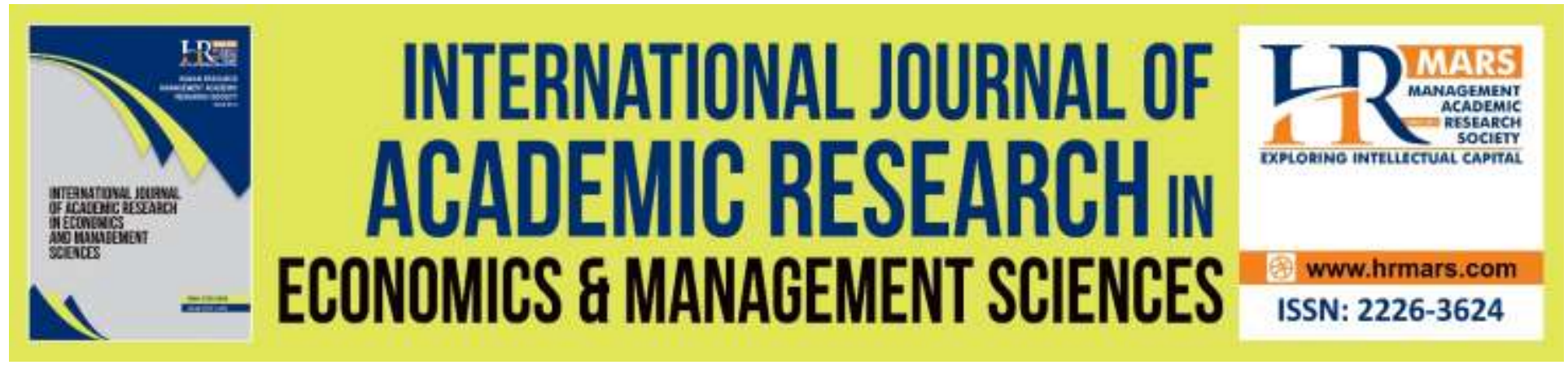

\title{
Does Foreign Direct Investment Crowd in or Crowd out Domestic Investment? Evidence from Panel Cointegration Analysis
}

\section{Nurul Azwanie Budang, Taufik Abd Hakim}

To Link this Article: http://dx.doi.org/10.6007/IJAREMS/v9-i1/7133

DOI:10.6007/IJAREMS/v9-i1/7133

Received: 13 Jan 2020, Revised: 09 Feb 2020, Accepted: 11 March 2020

Published Online: 27 March 2019

In-Text Citation: (Budang \& Hakim, 2020)

To Cite this Article: Budang, N. A., \& Hakim, T. A. (2020). Does Foreign Direct Investment Crowd in or Crowd out Domestic Investment? Evidence from Panel Cointegration Analysis. International Journal of Academic Research in Economics and Managment and Sciences, 9(1), 49-65.

Copyright: (C) 2020 The Author(s)

Published by Human Resource Management Academic Research Society (www.hrmars.com)

This article is published under the Creative Commons Attribution (CC BY 4.0) license. Anyone may reproduce, distribute, translate and create derivative works of this article (for both commercial and non-commercial purposes), subject to full attribution to the original publication and authors. The full terms of this license may be seen at: http://creativecommons.org/licences/by/4.0/legalcode

Vol. 9, No. 1, 2020, Pg. 49 - 65

http://hrmars.com/index.php/pages/detail/IJAREMS

JOURNAL HOMEPAGE

Full Terms \& Conditions of access and use can be found at http://hrmars.com/index.php/pages/detail/publication-ethics 


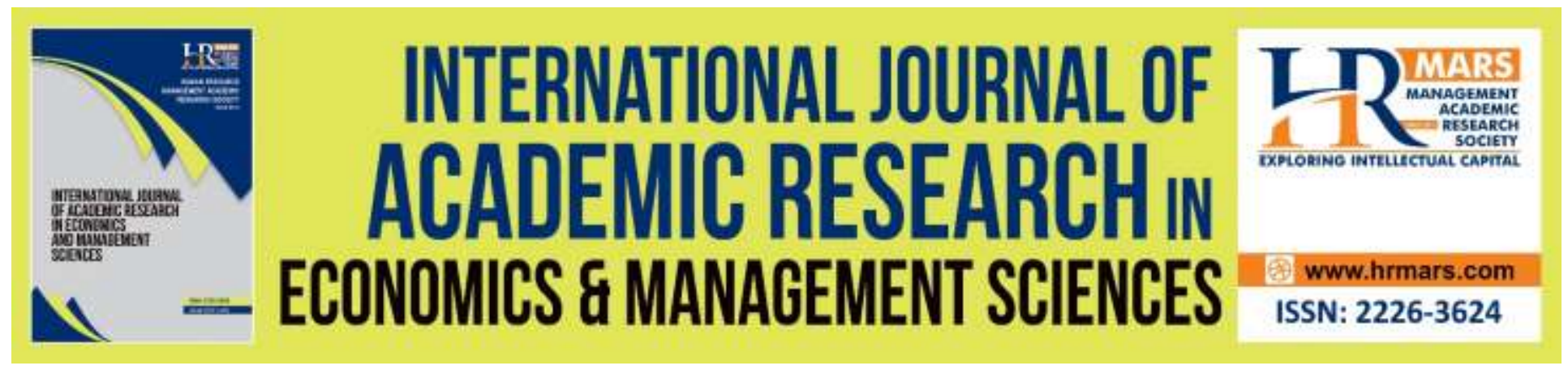

\title{
Does Foreign Direct Investment Crowd in or Crowd out Domestic Investment? Evidence from Panel Cointegration Analysis
}

\author{
Nurul Azwanie Budang,Taufik Abd Hakim \\ Faculty of Business and Management Universiti Teknologi MARA (UITM), Malaysia \\ Email: nurulazwanie94.NA@gmail.com, taufik4955@uitm.edu.my
}

\begin{abstract}
This paper investigates the crowding effects of foreign direct investment (FDI) on domestic investment (DI) in 38 Asian countries throughout 1993-2016. A first-generation panel unit root test was undertaken, and the relationship among variables in the long-term period was confirmed by the results generated by Kao-type cointegration and Westerlund-type cointegration estimators. Consequently, the fixed effect regression model suggested a significant but negative effect of FDI on the performance of DI. The long-term crowding effects equation was performed to support the regression results, and it revealed the existence of the crowd-out effect of FDI on DI. In short, FDI is significant in influence the performance of DI although the effect on local firm is unfavourable. Thus this study concludes that FDI inflows by no means always promise a good effect. In fact, instead of helping local firms out, the inflow of FDI may endanger local firms by crowding them out of the Asian business market.
\end{abstract}

Keywords: Foreign Direct Investment, Domestic Investment, Crowding In-Out, Cointegration, Fixed Effect Regression

\section{Introduction}

Following the collapse of the Bretton Woods system in the 1970s, cross-border investment has been widely used by countries as a tool for economic development and economic growth. In many economics literature works, cross-border investment, also known as FDI, has become a much-debated controversial issue. The Organisation for Economic Co-operation and Development (OECD (1996) described a foreign direct investment (FDI) as an incorporated or unincorporated enterprise in which a foreign investor owns 10 percent or more of the ordinary shares or voting power of an incorporated enterprise or the equivalent of an unincorporated enterprise. The general purpose of allowing the inflow of FDI makes this variable important in every country, especially for the development of domestic investment (DI). For example, De Mello (1999) mentioned that attracting FDI inflows is one of the country's strategies to fill in the DI gaps, especially so for developing countries. Besides, increasing the number of FDI inflows will 
raise international competition in the business market, thus compelling local firms to be more efficient. Consequently, this increased competition will provide a wider variety of choices to customers. Despite that, Fry (1993) provided evidence through his paper that an increase in FDI inflow drives an increase in capital formation (DI) in South and East Asia. Allowing FDI inflow is one of a country's strategies to expand its DI.

The Asian region is a compelling case for investigating the dynamic impact of FDI on DI by focusing on the financial crisis of 1997. The crisis, a phenomenon that took place after the collapse of the Bretton Woods system, created such a big scar on the affected countries, especially the developing Asian countries. This Asian financial crisis was once considered the worst crisis ever experienced by Asian countries. During the Asian financial crisis, the five most affected countries, which are Thailand, the Philippines, Malaysia, Indonesia, and South Korea, suffered considerable shocks from the crisis which almost drowned them into critical moments. The crisis pushed the countries' gross domestic product (GDP) and DI to the edge.

Interestingly, the deeper the crisis attacked those five countries, the higher the number of FDI inflows into those countries. The inconsistent trends in FDI inflow and the drop in DI rates during the Asian crisis raised debates among the academia and researchers on the issue of whether FDI affects DI positively or otherwise. Most of the studies, such as Haq and Zhu (2016), Sohn (2014), and Tang, Selvanathan, and Selvanathan (2008) found that FDI contributes a positive effect to DI. Thus, this study dug deeper into this issue with the assumption of an inextricable link existing between the two types of investment, namely FDI and DI.

From the above discussion, FDI undoubtedly plays a considerable role in economic growth and development, especially for developing countries. However, in the late 1990s, economics literature started to raise questions regarding the spillover effect of FDI on DI. The number of studies on this issue kept growing, with mixed results. For example, the studies conducted by Lean and Tan (2011) and Hanif and Jalaluddin (2014) that investigated the linkage between FDI and DI in the case of Malaysia found inconsistent and mixed results. Lean and Tan (2011), in their study covering the period of 1970-2009, found that FDI had a positive and significant impact on DI, which means that FDI tended to crowd in the DI in Malaysia. On the contrary, Hanif and Jalaluddin (2014) found a crowding out (negative) relationship between FDI and DI in the case of Malaysia for a period of 42 years throughout 1970-2011. Meanwhile, Agosin and Machado (2005) and Gocer, Mercan, and Peker (2014) explored the crowding effect of FDI on DI in some developing countries by separating those countries into three regions, namely Asia, Africa, and Latin America. By applying pooled estimations of seemingly unrelated regressions (SUR), Agosin and Machado (2005) found the existence of a crowd-in effect in Asia and Africa but a crowd-out effect in Latin America. Meanwhile, Gocer et al. (2014) found evidence of a crowd-in effect in both Asia and Latin America and a crowd-out effect of FDI on DI in Africa. These inconsistent results drew our attention to investigate further on the issue.

As reported in World Investment Report 2017 concerning the issue of the digital economy and FDI, developing and least developed countries face challenges due to inadequate infrastructure and difficulty in obtaining finance (United Nations Conference on Trade and Development(UNCTAD, 2017). The digital technology growth and the important role of FDI inflow make it difficult for DI to compete, which leaves the developing and least developed countries one step behind the developed countries. This problem is quite widespread among developing and least developed countries. Demirhan and Masca (2008) reviewed the financing issue often 
faced by developing and least developed countries due to the lack of capital formation suffered by those countries. Moreover, Gurara et al. (2017) and Acquah (2017) proposed the idea that FDI is much more crucial than DI in developing and least developed countries.

To thoroughly investigate the issues concerning the relationship between FDI and DI, the researcher selected the Asian region as the scope of this study since this region mostly consists of developing countries. As previously highlighted by Demirhan and Masca (2008), developing countries experience difficulties in financing their capital, thus compelling them to attract more foreign investments. Based on the history of the Asian financial crisis of 1997, FDI was widely used as a tool to fix the countries that suffered from the crisis. Initially, most of the affected Asian countries faced pressure during the crisis, which led them to obtain loans from international banks. However, commercial banks could not afford to provide large amounts of loans to the affected countries that were suffering from a debt crisis. Consequently, FDI became an alternative to bank loans as a source of capital inflows and contributed to the Asian crisis recovery process. Once again, this study questions whether FDI crowds in (helps) or crowds out (competes with) DI for the case of Asian countries?

Gocer et al. (2014) and Agosin and Mayer (2000) awareof the crucial role of FDI in developing countries and raise the issue of crowding effects of FDI on domestic investment, the Asia financial crisis in 1997 drew this study attention to focus on Asian countries. Both previous studies were not focusing on Asian countries as they more on comparing the effects in different regions. This study thoroughly investigates the relationship between the Asian financial crisis with the crucial role of FDI inflow into their region. As reported in the world investment report 1998, FDI inflow into 5 most affected countries (Thailand, Philippines, Malaysia, Indonesia, and South Korea) were not sensitive to the crisis. Instead, these affected countries recorded the highest FDI inflow into their countries (UNCTAD, 1998). Besides UNCTAD (1998) also reported the large number of M\&a flows into these 5 affected led by the firms from Singapore and the United States during the second half of 1997. This issue attracts this study to focus on the effects of FDI inflow on DI in Asian countries. The table below shows a comparison between this study with previous works.

Table 1: Comparison of the current study with previous studies

\begin{tabular}{|c|c|c|c|}
\hline $\begin{array}{c}\text { Componen } \\
\text { ts }\end{array}$ & This Study & $\begin{array}{l}\text { Gocer, Mercan, and Peker } \\
\qquad(2014)\end{array}$ & Agosin and Mayer (2000) \\
\hline Country & $\begin{array}{l}\text { Asia Countries } \\
\text { (38 Countries) }\end{array}$ & $\begin{array}{c}\text { Developing countries (Asia }=9 \\
\text { countries) } \\
\text { (Africa }=8 \text { countries) } \\
\text { (Latin America/Carribean }=11 \\
\text { countries) } \\
\text { (Transition economies }=2 \\
\text { countries) }\end{array}$ & $\begin{array}{c}32 \text { Developing countries (Asia = } \\
8 \text { Countries) (Africa }=12 \\
\text { Countries) } \\
\text { (Latin America }=12 \text { Countries) }\end{array}$ \\
\hline $\begin{array}{l}\text { Period Of } \\
\text { Study }\end{array}$ & 1993-2016 (24 years) & $\begin{array}{l}1992-2010 \\
\text { (18 years) }\end{array}$ & $\begin{array}{c}1970-1996 \text { (27 years) } \\
(1976-1985) \\
(1986-1996) \\
\end{array}$ \\
\hline Method & $\begin{array}{l}\text { Static Panel Approach, } \\
\text { Instrumental Variables, and } \\
\text { Long term crowding effect }\end{array}$ & $\begin{array}{c}\text { Generalized Method of } \\
\text { Moment (GMM) }\end{array}$ & $\begin{array}{l}\text { Pooled Estimations of } \\
\text { Seemingly Unrelated } \\
\text { Regression (SUR) }\end{array}$ \\
\hline
\end{tabular}




\section{Theory and Literature Review}

\section{Hymer Theory of Foreign Direct Investment (FDI)}

The theory of Foreign Direct Investment (FDI) was first developed by Hymer 1960 published in 1976. Before Hymer (1976) started his theory, all investments across the border are explained by using the existence theory of capital transfer between different countries (Badayi, 2017) such as Ricardo's theory of comparative advantage (Denisia, 2010), and Heckscher-Ohlin theorem (HO). However, Hymer (1976) argued that the theory of international capital movement does not apply for direct investment as the theory only explains the movement of capital but not to direct investment, where the investor directly controls the foreign enterprise. The theory of international capital movement mainly suggests that the differences in interest rates are an important reason for the capital to be the move in.

Hymer (1976) suggested that FDI will be performing with two main significant determinants and the key assumption for both determinants is the existence of market imperfections. The determinants of direct investment are as follows:

\section{1) Specific Advantage}

Hymer (1976) believed that the local firm will always have better information about the local economic environment. It might be impossible for FDI to be a success without possessing certain advantages that allow such an investment to be viable. Moreover, exploitation of advantage by the foreign market will enhance further their market power and thus it will raise the overall level of the imperfect market.

\section{2) Imperfect Market}

The competition will always rise as the more firms enter the business market. It is commonly

called a perfect market. In the condition of a perfect market, FDI may be difficult to move in.

These conflicts or competition, however, can be removed either via merging with the firm in

other countries or by taking over the existing firm.

In short, the theory of FDI by Hymer (1976) is focused on controlling and ownership. Hymer (1976) suggest that Foreign Direct Investment (FDI) can move in if the firm possesses a specific advantage in the foreign country which can enhance their market power through the imperfect market. According to Dunning and Lundan (2008), domestic firms can go multinational if they have innovative and own some kind of financial or marketing skill. It also brought the meaning that, if the firm possesses these advantages, it can compete with its rival and most likely the firm will take over the market and outweigh the domestic firms.

\section{Literature Review}

Some economics literature works have focused on investigating the crowding effect of FDI on DI in a single country along with a cross-country analysis. In a single country analysis, Sohail, Rehman, and Azeem (2014) conducted a study of FDI and DI for the case of Pakistan. Based on their empirical analysis using the regression model and correlation technique, FDI was claimed to have a complementary (crowd-in) effect rather than a substitution (crowd-out) effect. Subsequently, Haq and Zhu (2016) found mixed findings where FDI was proven to have a crowd- 
in effect in Pakistan but a crowd-out effect in India in the long run. They implicitly and explicitly investigated the issue of FDI and DI by implementing the cointegration and error correction model (ECM) on time series analysis for the period of 1978-2013. Moreover, they stated that the crowd-in effect in India was more elastic than the substitution (crowd-out) effect in Pakistan, which experienced inelasticity.

The studies by Al-Sadig (2013) and Morrissey and Udomkerdmongkol (2012) looked at the impact of FDI on DI in a cross-country analysis by focusing on developing countries. Al-Sadig (2013) applied a system GMM panel analysis covering the period of 1970-2000, and the empirical result revealed that a 1 percent increase in FDI can raise domestic private investment by 9 percent (crowd-in). Interestingly, contradictory evidence was revealed by Morrissey and Udomkerdmongkol (2012), where FDI was detected to influence DI negatively in the host developing countries for the period of 1996-2009. This contradictory result could be due to the inclusion of governance factors, which were not considered in the study by Al-Sadig (2013). Morrissey and Udomkerdmongkol (2012) considered the role of political stability and corruption as governance factors that might have contributed to the increase and decrease in DI. Their empirical findings revealed that FDI crowded out DI in periods of political stability.

In another study, Wang (2010) used a large sample size consisting of 50 developed and less developed countries to investigate the effect of FDI on DI. The study provided evidence of the crowd-out effect of FDI on DI in developed countries and a neutral effect of FDI on DI in less developed countries over the short term. However, in the long-term period, FDI was found to have a neutral effect on DI in developed countries and a crowd-in effect in the least developed countries. Before that, Lipsey (2000) conducted a study to investigate the effect of FDI on DI in OECD countries throughout 1970-1995. The study found a negative correlation between FDI inflow and DI, but the impact is relatively small.

Another study on the crowding effect of FDI on DI in a single country in Asia, namely Vietnam, was carried out by Pham (2016). The study divided the single country analysis into crosssectional dimensions by focusing on domestically owned Vietnamese firms. By applying a dynamic GMM approach on unbalanced panel data for the period of 2001-2010, the empirical findings provided evidence of a crowd-out effect of FDI on Vietnamese domestically owned firms. Vietnamese firms were found to have a high tendency to lose their market share to foreignowned competitors due to intense competition among the firms. However, the inflow of FDI may also benefit their industry. The empirical study concluded that while FDI can crowd out domestically owned firms, it does not influence their industry; instead, it contributes to a positive spillover effect.

Some of the previous studies obtained mixed findings on the effect of FDI on DI. In essence, this paper concludes that the similarity or difference in method, region, studied period, and variables might have contributed to the similarity or difference in findings. This gap and inconsistent trends in investment, namely FDI and DI, motivated the researcher to investigate further on the crowding effects of FDI on DI in the Asian region in different phases (before, during, and after) of the Asian financial crisis.

\section{Data and Methodology}

The scope of this study covers 38 Asian countries throughout 1993-2016. Data were collected from World Bank (2018) and UNCTAD (2018) for five variables, namely domestic 
investment (DI), foreign direct investment (FDI), gross domestic product (GDP), broad money (M3), domestic credit to private sector (DCT), and gross domestic saving (GDS). All these data are in percentage of GDP and annual percentage.

As the sample of the study is subject to the measurement of multidimensional data over time, balanced panel data analysis is the most appropriate approach. Therefore, a static panel data approach involving panel OLS, fixed effect (FE), and random effect (RE) estimations were taken into consideration. Since Breusch Pagan Langarian Multiplier (BPLM) test failed to reject the null hypothesis of pooled OLS, the Hausman test and Sargan-Hansen test were applied in choosing between FE and RE estimations. Besides, this study is aware of the possibility of bias in the model due to the presence of econometric problems, such as autocorrelation, heteroskedasticity, multicollinearity, cross-section dependence, and endogeneity. Thus, a robust standard error was applied to deal with autocorrelation and heteroskedasticity, while instrumental variables (IV) was used to deal with endogeneity. Here, DI and FDI were assumed to be endogenous, which is the root of the endogeneity problem. Variance inflation factor (VIF) and Pesaran CD tests were performed to detect multicollinearity and cross-section dependence.

In this study, the model of investment adopted follows the model proposed by Agosin and Machado (2005):

$$
I_{i, t}=\alpha+\beta_{1} F_{i, t}+\beta_{2} F_{i, t-1}+\beta_{3} F_{i, t-2}+\beta_{4} I_{i, t-1}+\beta_{5} I_{i, t-2}+\beta_{6} G_{i, t-1}+\beta_{7} G_{i, t-2}+\eta_{t}+\varepsilon_{i, t},
$$

where $\alpha$ represents a constant, $\mathrm{I}=$ the share of investment per GDP ratio, $\mathrm{F}=$ inward FDI per GDP ratio, $\mathrm{G}=$ growth rate of GDP, $\eta=$ time dummies, and $\varepsilon=$ serially uncorrelated random error.

However, this study included other significant variables, which were found in the studies by Olweny and Chiluwe (2012), Khatib, Altaleb, and Alokor (2012), and Elhiraika (2001), in model regression (1). Therefore, the empirical model for this study is as follows:

$$
L D I_{i t}=\alpha+\beta_{1} L F D I_{i t}+\beta_{2} L G D S_{i t}+\beta_{3} L G D P_{i t}+\beta_{4} L M 3_{i t}+\beta_{5} L D C T_{i t}+\varepsilon_{i t}
$$
and

$$
L D I_{i t}=\alpha+\beta_{1} L F D I_{i t}+\beta_{2} L F D I_{i t-1} \beta_{3} L D I_{i t-1}+\beta_{4} L G D S_{i t}+\beta_{5} L G D P_{i t}+\beta_{6} L M 3_{i t}+
$$

where DI represents domestic investments, FDI is foreign direct investment, and the explanatory variables are GDS (gross domestic saving), GDP (gross domestic product), M3 (broad money), and DCT (domestic credit to the private sector). The data for all the variables are measured in the natural logarithm and expressed as LDI, LFDI, LGDS, LGDP, LM3, and LDCT. Moreover, $\alpha$ is a constant, $\beta_{1}-\beta_{7}$ represent the parameters of the explanatory variables to be estimated, $\varepsilon$ proxies the error term, and $i$ and $t$ denote the cross-section and time dimension, respectively.

The original model (2) in this study is extended into the regression model (3) by adding some of the lagged variables of DI and FDI. As the lagged variables are created as in (3), the longrun crowding effect coefficient applied is as follows:

$$
b_{L T}=\frac{\sum_{i=1}^{2} \beta_{i}}{1-\sum_{i=3}^{3} \beta_{i}}
$$

where $b_{L T}$ denotes the long-run coefficient, $\sum_{i=1}^{2} \beta_{i}$ is the total coefficient of FDI, while $\sum_{i=3}^{3} \beta_{i}$ is the total coefficient of DI in the regression model. Due to Agosin and Mayer (2000) and Agosin 
and Machado (2005), the measurement of the long-term crowding effect is determined at three levels:

1) $b_{L T}=1$ An increase in FDI by one dollar (or, more precisely, by one percentage point of GDP) in the long run leads to an increase in the total investment by one dollar (or investment amounting to one percentage point of GDP).

2) $b_{L T}>1$ (Crowding in effect); an increase in one dollar of FDI leads to an increase in more than one dollar of total investment

3) $b_{L T}<1$ (Crowding out effect); The situation when one additional dollar of FDI causes the total investment to increase by less than one dollar. In other words, there is a substitution effect of DI by FDI.

\section{Results and Discussion}

\section{Empirical Results}

\section{Descriptive Statistic}

Table 4.1a explains the descriptive statistic for the period (1993-2016). DI reported an average mean with 20.70 percent and standard error 9.19 where Bhutan collected the highest value of maximum DI (66.65percent) while the minimum rate of DI (0.21percent) is held by Yemen. Meanwhile, the highest maximum rate and the minimum rates of FDI are 58.51 percent and 3.69 percent with an average mean of 4.58 percent. For GDP, M3, DCT, and GDS, the table reported that average mean contributes within range 5-73percent.

Table 4.1a: Summary statistics of domestic investment and macroeconomic variables in 38 Asian countries

\begin{tabular}{|c|c|c|c|c|c|}
\hline Variables & Indicators & Mean & $\begin{array}{l}\text { Standard } \\
\text { Deviation }\end{array}$ & Min & Max \\
\hline Domestic Investment (DI) & $\%$ of GDP & 20.7044 & 9.18519 & 0.20834 & 66.6475 \\
\hline $\begin{array}{l}\text { Foreign Direct Investment } \\
\text { (FDI) }\end{array}$ & $\%$ of GDP & 4.57557 & 6.88424 & $3.69 E-06$ & 58.5149 \\
\hline $\begin{array}{l}\text { Gross Domestic Product } \\
\text { (GDP) }\end{array}$ & annual \% & 5.92672 & 4.4123 & 0.01735 & 37.1468 \\
\hline Broad Money (M3) & $\%$ of GDP & 72.262 & 60.8424 & 0.00146 & 376.49 \\
\hline $\begin{array}{l}\text { Domestic Credit to Private } \\
\text { Sector (DCT) }\end{array}$ & $\%$ of GDP & 52.8447 & 45.4552 & 0.00082 & 233.211 \\
\hline $\begin{array}{l}\text { Gross Domestic Saving } \\
\text { (GDS) }\end{array}$ & $\%$ of GDP & 26.7846 & 15.0287 & 0.09698 & 74.2921 \\
\hline
\end{tabular}

Notes: $\mathrm{n}=38$ countries of Asia, $\mathrm{N}=912$ observations and $\mathrm{T}=24$ years for the total period 19932016.

For our analysis, we first performed the panel unit root test due to the importance of determining the presence of a unit root in each variable to avoid spurious regression or the random walk issue. A variablethat contains a unit root is often called a non-stationary variable, and the presence of this variable leads to aggregation bias that distorts the empirical model as a 
INTERNATIONAL JOURNAL OF ACADEMIC RESEARCH ECONOMICS AND MANAGEMENT SCIENCES

Vol. 9, No. 1, 2020, E-ISSN: 2226-3624 ㄷ 2020 HRMARS

whole. Following the process, fixed effect regression and the instrumental variables involved are displayed in this section.

\section{Panel Unit Root}

Table 4.1b: Results of unit root tests

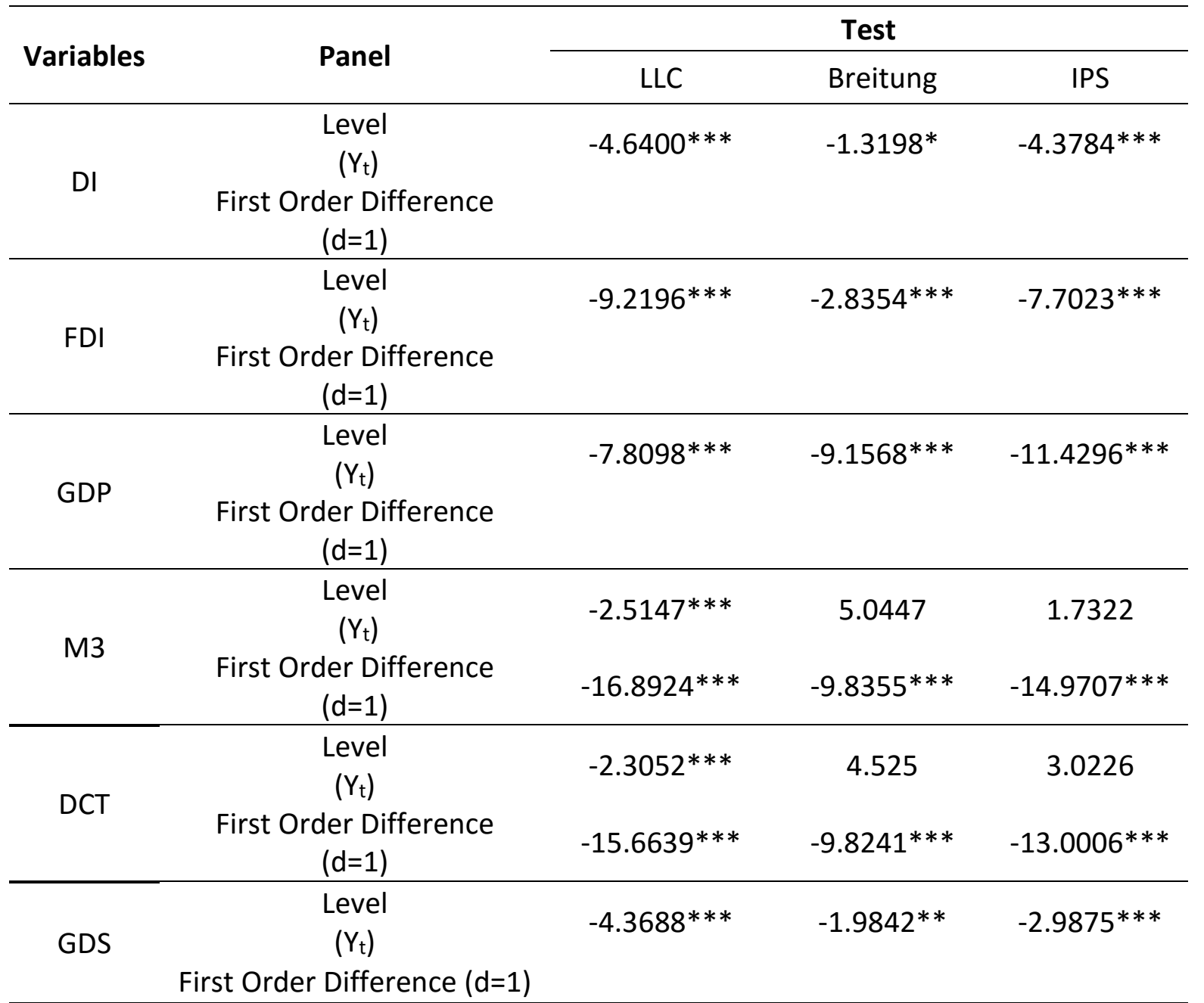

Notes: The critical values are based on the percentage levels of $1 \%, 5 \%$, and $10 \%$, which correspond to the confidence levels of $99 \%, 95 \%$, and $90 \%$, respectively. ${ }^{* * *}, * *$, and $*$ indicate significance at levels of $1 \%, 5 \%$, and $10 \%$, respectively.

The table above shows the necessary procedure for the panel unit root test, which involved level series and first-order difference on six macroeconomic factors. The LLC test shows that all the six macroeconomic variables are significant at level series at a 1 percent significance level. Consequently, the LLC test rejects the null hypothesis that the panel series has a unit root with a 99 percent confidence level. Here, the LLC test affirms that the effort of level series is stationary for all the six-panel series data. The Breitung and IPS test show that only M3 and DCT are insignificant at 1, 5, and 10 percent levels. Thus, this study fails to reject the null hypothesis that the panel series is stationary at level. Concerning this matter, both the Breitung and IPS tests have confirmed that all the six variables are significant at the first-order difference at a 1 percent significance level. 
INTERNATIONAL JOURNAL OF ACADEMIC RESEARCH ECONOMICS AND MANAGEMENT SCIENCES Vol. 9, No. 1, 2020, E-ISSN: 2226-3624 @ 2020 HRMARS

\section{Regression Result}

Table 4.1c: Regression table for fixed effect and IV regression in Asia for the entire period of 1993-2016

\begin{tabular}{|c|c|c|c|c|c|}
\hline \multirow{2}{*}{ Variables } & \multirow{2}{*}{ Coefficient } & \multicolumn{4}{|c|}{ ENTIRE PERIOD (1993-2016) } \\
\hline & & (1) & (3) & (2) & (4) \\
\hline FDI & $\begin{array}{c}\left(Y_{t}\right) \\
(d=1)\end{array}$ & $\begin{array}{c}-0.0630 * * \\
(0.0261) \\
\end{array}$ & $\begin{array}{c}-0.0880 * * * \\
(0.0241)\end{array}$ & $\begin{array}{c}-0.1537 * * * \\
(0.0337)\end{array}$ & $\begin{array}{r}-0.0880 * * * \\
(0.0125)\end{array}$ \\
\hline L1.FDI & $\begin{array}{c}\left(Y_{t}\right) \\
(d=1)\end{array}$ & & $\begin{array}{c}0.0599 * * * \\
(0.0217) \\
\end{array}$ & & $\begin{array}{c}0.0599 * * * \\
(0.0113) \\
\end{array}$ \\
\hline L1.DI & $\begin{array}{c}\left(Y_{t}\right) \\
(d=1)\end{array}$ & & $\begin{array}{c}0.4875 * * * \\
(0.0464) \\
\end{array}$ & & $\begin{array}{c}0.4875^{* * *} \\
(0.0268) \\
\end{array}$ \\
\hline GDP & $\begin{array}{c}\left(Y_{t}\right) \\
(d=1)\end{array}$ & $\begin{array}{c}-0.0556 * * \\
(0.0242) \\
\end{array}$ & $\begin{array}{l}-0.0283 \\
(0.0181) \\
\end{array}$ & $\begin{array}{c}-0.0444 * * * \\
(0.0179) \\
\end{array}$ & $\begin{array}{c}-0.0283 * * \\
(0.0143) \\
\end{array}$ \\
\hline M3 & $\begin{array}{c}\left(Y_{t}\right) \\
(d=1)\end{array}$ & $\begin{array}{c}-0.1979 * * * \\
(0.0636)\end{array}$ & $\begin{array}{c}-0.1366 * * \\
(0.0508) \\
\end{array}$ & $\begin{array}{c}-0.2079 * * * \\
(0.0863)\end{array}$ & $\begin{array}{c}-0.1366 * * \\
(0.0703) \\
\end{array}$ \\
\hline DCT & $\begin{array}{c}\left(Y_{t}\right) \\
(d=1)\end{array}$ & $\begin{array}{c}0.2239 * * * \\
(0.0676) \\
\end{array}$ & $\begin{array}{c}0.1621 * * * \\
(0.0521)\end{array}$ & $\begin{array}{c}0.2394 * * * \\
(0.0834) \\
\end{array}$ & $\begin{array}{c}0.1621 * * * \\
(0.0679) \\
\end{array}$ \\
\hline GDS & $\begin{array}{c}\left(Y_{t}\right) \\
(d=1)\end{array}$ & $\begin{array}{c}0.0496 \\
(0.0404) \\
\end{array}$ & $\begin{array}{c}0.0199 \\
(0.0241) \\
\end{array}$ & $\begin{array}{l}0.0491^{*} \\
(0.0283) \\
\end{array}$ & $\begin{array}{c}0.0199 \\
(0.0232) \\
\end{array}$ \\
\hline \multicolumn{2}{|l|}{ Constant } & $\begin{array}{c}2.8714 * * * \\
(0.1312)\end{array}$ & $\begin{array}{c}1.4908 * * * \\
(0.1602)\end{array}$ & $\begin{array}{c}2.9083^{* * *} \\
(0.0895)\end{array}$ & $\begin{array}{c}1.4908 * * * \\
(0.1041)\end{array}$ \\
\hline \multicolumn{2}{|c|}{$\begin{array}{c}\text { Rsquared } \\
\text { Prob (F-Statistics) }\end{array}$} & $\begin{array}{l}0.0583 \\
0.0015\end{array}$ & $\begin{array}{l}0.3331 \\
0.0000\end{array}$ & $\begin{array}{l}0.2320 \\
0.0000\end{array}$ & $\begin{array}{l}0.3331 \\
0.0000\end{array}$ \\
\hline \multicolumn{2}{|c|}{ Breusch Pagan LM } & \multicolumn{4}{|c|}{0.0000} \\
\hline \multicolumn{2}{|c|}{ Hausman } & \multicolumn{4}{|c|}{0.0381} \\
\hline \multicolumn{2}{|c|}{ Wooldridge } & \multicolumn{4}{|c|}{0.0015} \\
\hline \multicolumn{2}{|c|}{ Modified Wald } & \multicolumn{4}{|c|}{0.0000} \\
\hline \multicolumn{2}{|c|}{ VIF } & \multicolumn{4}{|c|}{3.6500} \\
\hline \multicolumn{2}{|c|}{ Pesaran CD } & \multicolumn{4}{|c|}{0.4923} \\
\hline
\end{tabular}

Notes: (1), (2), (3), and (4) represent fixed effects with robust standard error (FE), fixed effects instrumental variables (FE-IV), FE with lagged variables, and FE-IV with lagged variables, respectively. Values in the parentheses are standard errors. The critical values are based on percentage levels of $1 \%, 5 \%$, and $10 \%$, which correspond to confidence levels of $99 \%, 95 \%$, and $90 \%$, respectively. $* * *, * *$, and $*$ indicate significance at levels of $1 \%, 5 \%$, and $10 \%$, respectively.

The empirical findings from the four estimation approaches for the period of 1993-2016 are presented in Table 4.1b. The whole model is pooled by either fixed effect (FE) or random 
effect (RE), as the BPLM test has confirmed to reject the null hypothesis of pooling by OLS. Therefore, the Hausman test has been applied, and the result confirms that the whole model is pooled by FE as the null hypothesis of pooling by RE is rejected. Moreover, the Wooldridge and Modified Wald tests reveal that the model suffers from autocorrelation and heteroskedasticity issues. However, no multicollinearity or cross-section dependence is detected in the model.

Meanwhile, all four estimator methods show a significant and negative effect of FDI on DI at both 1 percent and 5 percent levels. A 1 percent increase in FDI leads to a drop in DI within the range of $0.06-0.15$ percent. It indicates that the FDI inflow into host Asian countries competes with DI instead of helping to develop their domestic capital. Acar, Eris, and Tekce (2012) found similar results where FDI had a significantly negative and crowd-out effect on DI in the Middle East and North Africa (MENA) countries. They stated that the crowd out effect was caused by the direct flows of FDI into existing projects. This type of FDI inflow probably has no intention in creating new investments, as they aim to take over and run the existing business as usual.

Meanwhile, FE with lagged variables and FE-IV with lagged variables estimators show a positive relationship between lagged DI and lagged FDI with current DI. It reveals that the previous year's data for DI and FDI can positively affect the performance of the current DI. The effect is similar to the study by Acquah (2017) and Yao, Wang, Zhang, and Ou (2016) where they found the existence of a positive and significant effect of both lagged FDI and DI on the performance of current DI in China and Sub-Saharan Africa.

For the case of the control variables, all of them reported a significant effect of FDI on the flow of DI, except GDS that is significant only at 10 percent, as shown by the FE-IV estimator. However, only GDP and M3 reported a negative relationship with DI, where a 1 percent increase in GDP and M3 lead to a drop in DI by about 0.04-0.21. As thoroughly explained in the theory of investment by Keynes, an increase in economic growth (GDP) can raise the interest rate. This increased interest rate causes DI to be unattractive due to the high cost of borrowing (Froyen, 2013). The negative relationship between M3 and DI is supported by Adeoye (2007), Mohamed (2008), and Anastasia, Omade, and Osemen (2011). In their study, they mentioned that this negative effect is probably caused by inadequate investment funding, expensive funds for entrepreneurs, failure of the sector, and lack of confidence. The more available the domestic banks are to provide credit to investors (DCT), the more attractive DI is. This positive effect is consistent with the findings by Elhiraika (2001) and Khatib et al. (2012).

\section{Long-Term Results}

Kao Residual Cointegration Test

Table 4.2a: Kao residual cointegration test result

\section{ENTIRE PERIOD (1993-2016)}

\section{ADF}

$-7.545003 * * *$

Notes: The critical values are based on percentage levels of $1 \%, 5 \%$, and $10 \%$, which correspond to confidence levels of $99 \%, 95 \%$, and $90 \%$, respectively. $* * *, * *$, and $*$ indicate significance at levels of $1 \%, 5 \%$, and $10 \%$, respectively. 
As shown in Table 4.2a above, Kao residual cointegration test proves the existence of a long-run relationship between the dependent variable (DI) and independent variables (FDI, GDP, $M 3, D C T$, and GDS). As displayed above, Kao residual test rejects the null hypothesis of no longrun relationship between the dependent variable and independent variables at 1 percent as the $p$-value is less than 0.01. Thus, Kao concludes that a 1 percent increase in each of the independent variables (FDI, GDP, M3, DCT, and GDS) leads to a drop in DI by 7.55 percent.

Westerlund (2007) Cointegration Test

Table 4.2b: Westerlund (2007) cointegration test result

\begin{tabular}{ccccc}
\hline & Value & $Z$-value & $P$-value & Robust $P$-value \\
\hline $\mathrm{Gt}$ & -4.1480 & -7.5910 & 0.0000 & 0.0100 \\
$\mathrm{Ga}$ & -10.9590 & 5.5520 & 1.0000 & 0.0000 \\
$\mathrm{Pt}$ & -31.3330 & -14.2190 & 0.0000 & 0.0000 \\
$\mathrm{~Pa}$ & -12.8300 & 1.9480 & 0.9740 & 0.0100 \\
\hline
\end{tabular}

Notes: Gt and Ga represent group means statistic, while Pt and Pa are panels mean test. The $p$ value is a one-sided test that follows an asymptotic normal distribution. The robust $p$-value is based on a one-sided test by using a bootstrapped distribution with an optional 100 bootstrap replications. The bootstrap method of error-correction test is robust to the existence of crosssection dependence.

The null hypothesis for Westerlund (2007) determines that there is no cointegration for all the countries. Meanwhile, the alternate hypothesis is divided into two parts: the first alternative hypothesis is for Gt and Ga where at least one unit is cointegrated, and the second alternative hypothesis is for Pt and $\mathrm{Pa}$ which determines that the panel is cointegrated as a whole. Due to the asymptotic $p$-value above, only Gt and Pt were reported to be significant as the value is less than 0.05. Following the Monte Carlo simulation in Westerlund (2007), the highest power among the panel test and group mean test attribute by Pt and Gt as $p$-value are significant. By considering the existence of cross-section dependence, the robust $p$-values were generated from a bootstrapped distribution where all the tests reported significance with the robust $p$-values of less than 0.01. Based on the result of the Westerlund (2007) cointegration test, it is concluded that all the tests show the presence of a cointegration relationship among the variables. The finding is similar to the study by Hanif and Jalaluddin (2013) and Khatib et al. (2012). Thus, all the variables (DI, FDI, GDP, M3, DCT, and GDS) in this study are implied to be sustainable in the long run.

\section{Long-term Crowding Effects}

Table 4.2c: Long-term effects of foreign direct investment on domestic investment for the entire period of 1993-2016 in Asia

\begin{tabular}{ccc}
\hline Period & Long-term Coefficient between FDI and DI & Long-term Effects \\
\hline $1993-$ & -0.06 & crowd out \\
2016 & & \\
\hline
\end{tabular}

The crowding effects of FDI on DI in the long term are displayed in Table 4.1c above. As proven previously by Kao, Chiang, and Chen (1999) and Westerlund's (2007) co-integration test, the dependent variable (DI) and macroeconomic variables (FDI, GDP, M3, DCT, and GDS) are 
cointegrated. By using coefficient (4), the result for the long-term crowding effect revealed that FDI crowded out DI in the long term period of 1993-2016, as the coefficient is negative and less than 1. As explained in Agosin and Mayer (2000), FDI tends to crowd out DI, as the long-term coefficient is less than 1. A crowd-in effect occurs when the long-term coefficient is larger than 1 , and a neutral effect happens when the long-term coefficient is equal to 1 . This empirical result is similar to many empirical studies which support the crowd-out effect of FDI on DI in the long term for the case of Asia (Haq \& Zhu, 2016; Ivanovi'c, 2015; Pilbeam, 2012) and also other regions (Adams, 2009; Agosin \& Machado, 2005; Agosin \& Mayer, 2000; Szkorupová, 2015). By applying the long-term coefficient formula which was first proposed by Agosin and Mayer (2000), the result is explained as a 1 percent increase in FDI inflow leads to the crowding out of DI by 0.06 percent. It means that FDI can crowd out DI in Asian countries over a long-term period.

\section{Discussion}

Asian countries, which mostly consist of developing countries, find it hard to compete with foreign firms due to the difficulty in obtaining financial support, lack of advanced technology, or low power in global advertising and marketing. As discussed in World Investment Report by UNCTAD (1998), the 30 largest cross-border mergers and acquisitions (M\&A) during the Asian financial crisis were dominated by Asia including the five most affected countries (Thailand, the Philippines, Malaysia, Indonesia, and South Korea). Following the cross border $M \& A$, many local firms, especially small and medium enterprises, were crowded out of the market. Also, A. Desai, Fritz Foley, and Forbes (2004) explained in their study that a financial crisis relatively increases local firms' leverage for those that have borrowed in foreign currency due to the depreciation in the host currency, thus impeding their ability to acquire new equity. World Investment Report 2015 by UNCTAD (2015) reported that 'MNEs back on the acquisition trail,' indicating that cross border M\&A were again dominating the international investment market with 66 percent compared to greenfield investment, which experienced a decline by about 2 percent. The UNCTAD report shows that problems like lagging in technology and other sources and also the type of FDI (brownfield or greenfield investment) influence the crowding effect of FDI on DI in Asian countries.

\section{Conclusion}

Among a bundle of macroeconomic factors, FDI can be considered as one of the significant factors in explaining the volatility of DI. Many empirical studies approved the significant effect of FDI on DI. Without ignoring the crucial role of FDI in economic growth and development, Emmanuel and Kehinde (2018) indicated that DI will always have a higher priority over FDI, as FDI is only an external source or another alternative in boosting economic growth. The role of FDI caught global attention following the collapse of the Bretton Woods system. In Asia, FDI attracted interest worldwide during the Asian financial crisis. As the financial crisis causes the fall in economic growth and DI for most Asian countries, FDI came in at the right time through the implementation of brownfield investment (cross-border M\&A). As cross-border M\&A took over the market, many local firms, especially small and medium enterprises, pulled out or were forced out of the market due to the devaluation in the domestic currency and they failed to bear the high cost of borrowing. The issue of FDI concerning the Asian financial crisis raised the question of whether FDI can crowd out or crowd in DI for the case of Asia. 
To answer this question, a static panel approach, which is fixed effect regression was applied on an empirical model consisting of the economic variables, namely FDI, GDP, M3, DCT, and GDS on DI. Due to the possibility of aggregation bias driven by econometric problems like endogeneity and heterogeneity, we considered including instrumental variables in the fixed effect regression. In addition, for the case of the long-term relationship, we used the cointegration test and long-term crowding effect formula.

Our results reported that FDI has a significant and negative effect on DI. Moreover, the results are supported by the cointegration test and long-term crowding effect formula, which also found a significant and crowd-out effect of FDI on DI in the long run. FDI may affect our country favorably but not on DI, as it can crowd out local firms from the market.

\section{Policy Implication and Recommendations}

Theoretically, this study creates similar and also contradictory results from the previous studies. For example, as this study found crowd-out effect of FDI on DI in 38 Asian countries, it does support the study by Morrissey and Udomkerdmongkol (2012) which also reported crowdout effect of FDI on DI in developing countries with the involvement of political stability factor. In contrast to the finding by Lean and Tan (2011) which found a crowd in effect of FDI in Malaysia caused by good collaboration between FDI and DI. However, this study assumes the crowd out effect which is due to the type of entry modes of FDI as what had been happened on DI during the Asia crisis in 1997. As explained in Hymer's theory of FDI in section two, for FDI to survive and compete within the business market they need to at least possess specific advantages and move in through the imperfect market which makes them have a strong position in the market. However, this study suggests that the Hymer theory of FDI also best be practice for a local firm or domestic investment in order for them to compete with a foreign firm and build a strong position in the business market globally. Thus, as they have a strong position in the business market, for example, they contribute by their great marketing, variety choice of product or go through the imperfect market (via M\&A, joint venture) probably able to protect them from the crowd out.

On the other hand, this paper suggests that the country should implement a screening strategy to filter and select the type of FDI that is more beneficial to local firms and DI. For example, a vertical type of FDI may benefit local firms, especially those firms that supply product components that are needed by foreign firms. This type of FDI may be complementary to DI instead of substituting them. Nevertheless, we also recommend future researchers to take into consideration the power of advanced panel analysis that may generate better and more accurate results. Future research should also consider the type of FDI inflow, which might require them to separate FDI inflow into greenfield investment and brownfield investment and specifically examine which type of these entry modes of FDI will crowd in or crowd out domestic investment. In practical, this study probably significant for an investor either the foreign investor or local investor as this study provide an explanation on what type of FDI might benefit our local firm as well as how both local firm and foreign firm able to stay strong in the business market globally.

\section{References}

Desai, A. M., Foley, F. C., \& Forbes, K. (2004). Financial Constraints and Growth: Multinational and Local Firm Responses to Currency Crises. National Bureau of Economic Research, Inc, NBER Working Papers, 21. 
Acar, S., Eris, B., \& Tekce, M. (2012). The effect of foreign direct investment on domestic investment: Evidence from MENA countries. Paper presented at the European Trade Study Group 14th Annual Conference, Leuven, Belgium.

Acquah, J. W. (2017). Impact Of Foreign Direct Investment On Domestic Investment: Evidence From Sub-Saharan Africa. University of Lethbridge Lethbridge, Alberta, Canada.

Adams, S. (2009). Foreign Direct investment, Domestic Investment, and Economic Growth in SubSaharan Africa. Journal of Policy Modeling, 31(6), 939-949.

Adeoye, B. (2007). Financial sector development and economic growth: The Nigerian experience. Paper presented at the Selected papers for the 2007 Annual Conference of the Nigerian Economic Society held in Abuja, Nigeria.

Agosin, M. R., \& Machado, R. (2005). Foreign Investment in Developing Countries: Does it crowd in Domestic Investment? Oxford Development Studies, 33(2), 149-162.

Agosin, M. R., \& Mayer, R. (2000). Foreign investment in developing countries: Does it crowd in domestic investment? . UNCTAD Discussion Papers, 146.

Al-Sadig, A. (2013). The effects of foreign direct investment on private domestic investment: Evidence from developing countries. Empirical Economics, 44(3), 1267-1275.

Anastasia, O. C., Omade, S. I., \& Osemen, E. J. (2011). Long run relationship between private investment and monetary policy in Nigeria. Journal of Finance and Accounting, 2(6), 3039.

Badayi, S. A. (2017). A critical view of the theories of international production. Dutse Journal of Economics and Development Studies, 2(2), 151-161.

De Mello, L. R. (1999). Foreign direct investment-led growth: evidence from time series and panel data. Oxford economic papers, 51(1), 133-151.

Demirhan, E., \& Masca, M. (2008). Determinants of Foreign Direct Investment flows to developing countries: A cross-sectional analysis. Prague Economic Papers, 17(4), 356-369.

Denisia, V. (2010). Foreign Direct Investment Theories: An Overview of the Main FDI Theories. European Journal of Interdisciplinary Studies, 2(2), 104-110.

Dunning, J. H., \& Lundan, S. M. (2008). Multinational enterprises and the global economy (2nd ed.): Edward Elgar Publishing.

Elhiraika, A. B. (2001). Foreign capital inflow, domestic credit and private investment in Swaziland. Eastern Africa Social Science Research Review, 17(2), 69-90.

Emmanuel, O. G., \& Kehinde, A. (2018). Domestic Investment and Economy Growth in Nigeria: An Empirical Investigation. International Journal of Business and Social Science, 9(2), 130138.

Froyen, R. T. (2013). Macroeconomics theories and policies (10 ed.).

Fry, M. J. (1993). Some lessons for South Asia from developing country experience with foreign direct investment: World Bank, South Asia Region, Office of the Chief Economist.

Gocer, I., Mercan, M., \& Peker, O. (2014). Effect of foreign direct investments on the domestic investments of developing countries: A dynamic panel data analysis. Journal of Economic and Social Studies, 4(1), 73-90.

Gurara, D., Klyuev, V., Mwase, N., Presbitero, A., Xu, X. C., \& Bannister, G. (2017). Trends and challenges in infrastructure investment in low-income developing countries. IMF Working Paper, WP/17/233 
Hanif, A., \& Jalaluddin, S. (2013). FDI and Domestic Investment in Malaysia. International Proceedings of Economics Development \& Research, 76(4), 15-20.

Hanif, A., \& Jalaluddin, S. (2014). FDI and Domestic Investment in Malaysia 76(4), 15-20.

Haq, I. U., \& Zhu, S. (2016). Does FDI complement domestic investment? A comparative study of India and Pakistan. Актуальні проблеми економіки(5), 140-152.

Hymer, S. H. (1976). The international operations of national firms: A study of direct foreign investment. Massachusetts Institute of Technology, Cambridge.

Ivanovi'c, I. (2015). Impact of foreign direct investment (FDI) on domestic investment in Republic of Croatia. Munich Personal RePEc Archive, 70076.

Kao, C., Chiang, M.-H., \& Chen, B. (1999). International R\&D spillovers: An application of estimation and inference in panel cointegration. Oxford Bulletin of Economics and Statistics, 61(4), 693-711.

Khatib, H. B. A., Altaleb, G. S., \& Alokor, S. M. (2012). Economical Determinants Of Domestic Investment. European Scientific Journal, 8(7), 1-17.

Lean, H. H., \& Tan, B. W. (2011). Linkages between foreign direct investment, domestic investment and economic growth in Malaysia. Journal of Economic Cooperation and Development, 32(4), 75-96.

Lipsey, R. E. (2000). Interpreting developed countries' foreign direct investment. NBER Working Paper, 7810.

Mohamed, S. E. (2008). Financial-growth nexus in Sudan: empirical assessment based on an autoregressive distributed lag (ARDL) model. Arab Planning Institute Working.

Morrissey, O., \& Udomkerdmongkol, M. (2012). Governance, private investment and foreign direct investment in developing countries. World Development, 40(3), 437-445.

OECD. (1996). OECD Benchmark Definition Of Foreign Direct Investment (3rd ed.): Organisation For Economic Co-Operation And Development.

Olweny, T., \& Chiluwe, M. (2012). The effect of monetary policy on private sector investment in Kenya. Journal of Applied Finance \& Banking, 2(2), 239-287.

Pham, H. (2016). Foreign direct investment, productivity and crowding-out: Dynamic panel evidence on vietnamese firms. Paper presented at the Proceedings of Economics and Finance Conferences International Institute of Social and Economic Sciences.

Pilbeam, K. (2012). Does foreign direct investment crowd in or crowd out domestic investment? Evidence from the European Union. The Journal Of Economic Asymmetries, 9(1), 90-104.

Sohail, A., Rehman, U., \& Azeem, M. (2014). Economic Determinants of Domestic Investment: A Case of Pakistan Global Journal of Management and Business Research: B Economics and Commerce, 14(7), 41-44.

Sohn, C.-H. (2014). The nature of FDI competition in East Asia: Crowding-out or crowding-in?. Center for Economic and Social Studies in Asia (CESSA) Working Paper, 2014-01.

Szkorupová, Z. (2015). Relationship between Foreign Direct Investment and Domestic Investment in Selected Countries of Central and Eastern Europe. Procedia Economics and Finance, 23(2015), $1017-1022$.

Tang, S., Selvanathan, E. A., \& Selvanathan, S. (2008). Foreign Direct Investment, Domestic Investment, and Economic Growth in China. The World Economy, 31(10), 1292-1309.

UNCTAD. (1998). World Investment Report 1998: Trends and determinants: United Nation. 
INTERNATIONAL JOURNAL OF ACADEMIC RESEARCH ECONOMICS AND MANAGEMENT SCIENCES

Vol. 9, No. 1, 2020, E-ISSN: 2226-3624 ㄷ 2020 HRMARS

UNCTAD. (2015). World Investment Report 2015: Reforming International Investment Governance: United Nation.

UNCTAD. (2017). World Investment Report 2017: Investment and the Digital Economy: Unitad Nations.

UNCTAD. (2018). Foreign direct investment: Inward and outward flows and stock, annual. from UNCTADstats https://unctadstat.unctad.org/wds/TableViewer/tableView.aspx?Reportld=96740

Wang, M. (2010). Foreign direct investment and domestic investment in the host country: Evidence from panel study. Applied Economics, 42(29), 3711-3721.

Westerlund, J. (2007). Testing for error correction in panel data. Oxford Bulletin of Economics and Statistics, 69(6), 709-748.

World Bank. (2018). World development indicators (1464801630). from The World Bank Group https://data.worldbank.org/indicator/BX.KLT.DINV.WD.GD.ZS

Yao, S., Wang, P., Zhang, J., \& Ou, J. (2016). Dynamic relationship between China's inward and outward foreign direct investments. China Economic Review, 40, 54-70. 